\title{
1. European citizenship in perspective: history, politics and law An introduction
}

\section{Gerhard Hoogers}

One of the oldest and perhaps most important aspects of human society-building has always been the notion of belonging: not just in a cultural or moral sense, but also in a legal sense. Long before states in the modern sense of the word existed, polities throughout the world have made a distinction between those who belong to the polity and those who do not. Inside and outside - inclusion and exclusion have since time immemorial been important features to determine the status of human beings, often with far-reaching consequences for their lives and fate. The ambiguous meaning of the word hostis in Latin - meaning both guest and enemy - clearly illustrates this.

Over time, the terms citizen and citizenship have come to mean the exclusive relationship between a polity (and since the Westphalian peace treaties of 1648 we are wont to describe those as states) and its population, those who belong to its political and legal order. It is a rather intimate relationship: it brings on the one hand protection and privileges; but it entails on the other hand obligations, some far-reaching, up to and including the possible sacrifice of one's own life for the state.

The French Revolution has often been seen as the pivotal political and historical landmark to determine once and for all the meaning of citizenship in its modern form. And perhaps rightly so: one can argue convincingly that it has cast the mould from which the modern notion of citizenship has been formed for the vast majority of states that exist today, just as the 1789 Declaration of the Rights of Man and of the Citizen was the prime example for a modern catalogue describing the status of a citizen vis-à-vis a state.

But the classic concept of citizenship has not been left unchallenged. The project of European integration which started in 1951 with the 
European Coal and Steel Community and found its (tentative?) conclusion in the Lisbon Treaty of 2009 has produced, through the 1993 Maastricht Treaty, the notion of European citizenship. Every person holding the nationality, the citizenship of a Member State of the Union is qualitate qua a citizen of the Union itself. It is the first time in modern history that the status of citizenship has been granted to individuals not for being part of the legal order of a state, but because they form part of (and are subjects of) the legal order of an international organisation albeit a rather strange one. European citizenship is a clear example of a remarkable development: the EU is not a state, does not see itself as a state and does not want to be a state. Those analysing the Union often claim that the old idiom of constitutional and political theory - sovereignty, federalism, decentralisation and indeed citizenship - are no longer suitable to describe and explain the nature of the European Union. These terms are changed or modified, sometimes beyond recognition, they claim. And yet - as concepts like sui generis, post-state and post-national show - it is seemingly very hard to come up with a new set of terms or ideas that do justice to the novelties of EU reality.

European citizenship is perhaps the best example of this: the Union takes over a very old concept, which found its fixed meaning and context through the cataclysmic upheavals of the late eighteenth century. Yet it claims that this term finds a new meaning in the context of the Union, and this claim is often defended in literature on EU citizenship as well. The autonomous character of the EU - setting it apart from 'normal' international organisations - although defended by the European Court of Justice (ECJ) since the early 1960s, is quite often seen as becoming 'real' only since the inception of the Union's citizenship. Thus, the concept plays a very important role in legitimising the Union as a distinct polity.

Since its inception 25 years ago this new incorporation of an old idea has led to a flood of literature that can scarcely be overseen anymore. In a sense, the present volume is but a drop in that impressive ocean. It aims to bring together a number of scholars from different academic disciplines - history, political science, international relations and the law to investigate through this multifaceted lens some of the developments with regard to citizenship that have taken place in the EU in the last quarter century. It provides a historical account of the evolution of European citizenship and its institutionalisation, explaining why certain rights came into existence at a certain time, focusing on the actors involved. One of these actors is the ECJ, which has always treated European citizenship as a legal status independent from and in some respects superior to national citizenship. Through its case law, the Court has shaped and defined the citizenship of the Union as one of the most 
dynamic and important aspects of the Union's legal and political framework. Regarding the development of electoral rights of EU citizens, for example, the Court has been influential (Spain v UK; Eman and Sevinger; Delvigne).

The focus of this volume is mainly on the political-constitutional dimension of European citizenship, linking up with the right every European citizen has 'to participate in the democratic life of the Union', according to the Lisbon Treaty. It explores ways in which the connection between citizens and the European political institutions can be improved, by evaluating the European Citizens' Initiative (ECI) and by studying options of strengthening the intermediary role of the Europarties (for example by the introduction of pan-European lists of candidates). In this way, the volume also contributes to the debate on how to increase the democratic legitimacy of the EU. In combining the innovative approaches and insights of scholars from different disciplines - legal scholars, political scientists, historians and experts on international relations - this study overcomes the generally one-sided and monodisciplinary approach taken so often in the debate on EU citizenship.

This book starts with a contribution by Jan Willem van Rossem on the political dimension of citizenship. He argues that the citizenship the EU bestows is not a form of citizenship in a general sense, but it is (or has become increasingly) a form of political citizenship, dealing with true political or at least participatory rights. This form of political citizenship, Van Rossem argues, finds its original cast in the French Revolution and it expresses itself, among other ways, mainly in the right to take part in and stand during elections, up to and including the national parliament. EU citizenship comes with a right to take part in local elections in the Member State in which the EU citizen resides and the right to take part in the elections for the European Parliament (EP). After giving an overview of the different sources for EU citizenship in the primary and secondary law of the Union, he argues that through the case law of the ECJ the political dimension of the EU's citizenship has been strengthened. Starting out as a conditional right (the right to take part in municipal and EP elections as a special participatory right is linked to the movement to another Member State), since 2015 the ECJ has moved to a stance where the right to take part in EP elections is seen as an autonomous and q.q. right of citizens of the Union. He then analyses the genesis and evolution of the concept since the early 1950s, the 1976 Act and the Maastricht, Amsterdam and Lisbon Treaties, a development that has strengthened considerably the political dimension of the Union's citizenship - up to the point where the role of the EP is now no longer the representation of the Union's peoples, but the representation of the 
Union's citizens. He concludes by sketching a few of the challenges that lie ahead - mainly through a recent proposal by the Parliament to i.a. introduce a number of transnational seats in the Parliament and to change the wording of its representational task yet again, to secure the notion that all members of the EP represent all the Union's citizens.

The historical dimension pointed out by Van Rossem is further elaborated upon in the next two chapters of the book. The first of these (and the third chapter in the book) is authored by Anjo Harryvan and Jan van der Harst, who research the slow evolution of the concept of European citizenship since the 1970s. In European law, they argue, the origin of citizenship can be found in the free movement of persons regulated by the Treaties themselves and given direct effect and supremacy over domestic law by the Court in the early 1960s. The political interest in the transformation of this free movement into something more far-reaching can be traced back to the desire to enhance the standing of the European Communities on the world stage in the early 1970s and to strengthen the idea of 'belonging' to something more than a customs union. In countries which had many of their citizens living in other Member States for economic reasons, especially Italy, this was felt even more strongly.

Harryvan and Van der Harst show that, through various reports and against resistance from especially the northern Member States (the United Kingdom and Denmark among them), the idea of a citizenship on a European level found footing and was much fortified through the introduction of the direct elections of the EP in 1976 (implemented in 1979). It was especially new member Spain which promoted a stronger sense of belonging to the Community itself through a form of European citizenship by the end of the 1980s. Spain became the de facto leader of the Mediterranean Member States which had many nationals living in other Member States and who therefore desired to grant some form of legal recognition of their status in other Member States. Resistance to the concept came from the northern Member States, first and foremost the UK and Denmark, and to a lesser extent France and Germany. However, the specific political circumstances surrounding the end of the Cold War in the European theatre helped speed the process along; the Dutch presidency of the European Council at the time of the framing of the Maastricht Treaty was also in favour of the incorporation of the new status. Article 8-8e of the Maastricht Treaty contained the rights attached to the new European citizenship. But, as the authors show, this was mostly a cosmetic operation, merely confirming what had already been taking place in the case law of the ECJ. The 1999 Amsterdam Treaty (following a resounding Danish 'No' in the Maastricht referendum) 
therefore was very cautious in widening the scope of the Union's citizenship, and tried to strengthen the idea that it was an annex, not a replacement, of national citizenship. The authors conclude their contribution with the observation that because of the structural differences between 'north' and 'south' in the EU, it took the very specific circumstances surrounding the end of the Cold War and the unification of Germany to bring about European citizenship.

Chapter 4, by Tobias Nowak, also focuses on the historical dimension of EU citizenship. However, he focuses on the development of the rights annexed to the status of EU citizens. Nowak zooms in on the different processes in the EU with regard to economic rights on the one hand and political, civil and social rights on the other. He shows that the attribution of rights to individuals through European law began with the granting of free movement to coal and steel workers in 1952, extended to all workers in 1958 after the European Economic Community (EEC) Treaty came into force. Up until the 1970s, the Community provided for secondary law dealing with various aspects of this free movement of workers; this momentum slowed down because of the economic crisis of the 1970s. In the 1980s, Nowak shows, the process came back to speed through developments such as the Passport Union of 1981 and the Schengen Treaty of 1985. Later, free movement was extended beyond the scope of workers to include students, amongst others; the process of regulating economic rights came to a certain consolidation through a 2004 directive. As Nowak shows, the ECJ has also widened the scope of the number of persons falling within the parameters of the Union's norms on free movement, especially by making use of the core values of equality and non-discrimination.

The granting of political rights has also been gradual, but it met with far less resistance from northern Member States, especially Germany. The 2009 Lisbon Treaty consolidated these developments in granting to citizens of the Union a number of important political rights, such as the ECI. According to Nowak, the role of the ECJ in the evolution of these political rights was far less important than in the development of economic rights: it was mainly the Member States themselves that controlled and promoted this evolution.

Civil rights did not play an important role in the early stages of the European integration process and it was only through the case law of the German Federal Court that the ECJ began to acknowledge the importance of fundamental rights in the process of European integration. Since then, however, it has played a decisive role in the development of fundamental rights: it was the Court's opinion that the Union lacked the capacity to 
become a partner to the European Court of Human Rights (ECtHR) that led to the introduction of the Charter of Fundamental Rights, for instance. Since the ECJ still maintains that the Union cannot join the ECtHR without jeopardising the autonomous character of the Union's legal system, the importance of the Charter will only be strengthened.

Social rights, finally, are still rather few and far between in the Union; the Member States fear migration for financial reasons and the ECJ sees little room for further action, especially in an era of growing Euroscepticism.

The contributions by Harryvan and Van der Harst and Nowak both focus on the important role played by the Member States themselves in the development of the concept of citizenship and the rights attached to it. Jurian Langer's contribution in Chapter 5 stresses the role of the ECJ and specifically the methods of interpretation it uses in developing its case law on citizenship. Langer argues that the Court takes a cautious and limited approach in defining the Union's citizenship; in the case law of the ECJ, EU citizenship is a 'right to have rights', but mostly in the sense that it is a status that prevents from taking away certain rights, not so much a status granting rights in itself.

The ECJ has traditionally always stressed that there needs to be a transboundary element to the alleged infraction of rights in order for EU law (and therefore EU citizenship) to be relevant; but it has also, starting with its Garcia Avello and Zhu and Chen decisions in the early 2000s, stressed that such an element can be discerned quite easily. The landmark Rottmann case from 2010 showed a Court moving away from this pure transboundary approach to a more status-oriented perspective, according to Langer. This case dealt with an Austrian national who moved to Germany to escape criminal prosecution in Austria. He successfully opted for German citizenship and consequently lost his Austrian passport. When the German authorities discovered the criminal proceedings against him (of which he had remained silent during his naturalisation procedures) his German citizenship was revoked. The ECJ rejected the German claim that this case fell outside the scope of EU law, because it was a purely internal German decision. The Court stressed the fact that the decision by the German authorities to revoke Rottmann's German citizenship led him to lose the citizenship of the Union, which made it a case under EU law and therefore within the scope of its jurisdiction.

In the Ruiz Zambrano case (2011), the fact that a Colombian national with no residence or work permit in Belgium had two children with Belgian passports led the Court (combining Zhu and Chen and Rottmann) to the conclusion that Belgium could not extradite him because this 
would force his underage children to leave the Union's territory, effectively depriving them of the enjoyment of EU citizenship rights. Langer objects to this decision for its lack of conceptual underpinning and vagueness, thus depriving national courts from implementing it in their own case law. In the following McCarthy and Dereci cases (2011), the ECJ tried to bring better focus on the underpinnings of its case law, rectifying the mistakes made in Ruiz Zambrano. In the McCarthy case, the fact that Ireland refused Mrs McCarthy the right to bring her Jamaican husband to the EU did not lead to a serious infringement of her own rights as a citizen of the Union (thus clarifying the 'impeding effect' rule for testing national measures); in the Dereci case the Court ruled that a Turkish national, residing illegally in Austria, could not rightfully claim residency in Austria to live with his two (Austrian) children and his Austrian wife because they are citizens of the Union. His removal, so the Court ruled, does not deprive them of the genuine enjoyment of Union citizenship rights, thus clarifying the 'genuine enjoyment' test, the other threshold test first used in Ruiz Zambrano. In its CS and Rendón Marin cases (2016) the ECJ dealt with questions quite similar to Ruiz Zambrano and Dereci, but with a caretaking parent facing extradition after a criminal conviction. In both cases the Court argued that it was not inconceivable to extradite such a person from the territory of the Union, but that the circumstances of the case had to be taken into account carefully, especially given the rights granted in the Charter of Fundamental Rights. Langer concludes that especially the genuine enjoyment test is a threshold test, allowing the ECJ to set up standards for national courts to decide whether or not citizenship rights are infringed by national measures.

In Chapter 6, Richard Procee and Gerrit Voerman analyse the proposals made by the main Europarties and their Dutch member parties to foster the political participation of European citizens in the Union as a whole since the European elections of 1979. They research five subjects or clusters of these proposals which can be seen as relevant to strengthen the functioning of democracy and civil participation at the level of the EU: the adoption of a European constitution and EU citizenship; the creation of a common European electoral and party system; the strengthening of the European Parliament vis-à-vis the European Commission; the strengthening of the influence of the citizen on decision-making in the EU; and the creation of a truly European public sphere.

The authors find that in all these areas, the two most prominently pro-European parties - the progressive green GroenLinks and the socialliberal D66 - are the most consistent in their proposals and in the pro-European content thereof. The more right-wing liberal VVD and the 
Christian democratic CDA were quite strong supporters of strengthening the democratic character of the EU in the 1980s and the 1990s but have shifted their positions significantly since then. The social-democratic PvdA, whose position generally has been quite consistently pro-EU, is somewhat lacklustre and incoherent in promoting ideas to enlarge the influence of citizens on decision-making in the EU or the democratic character of the Union. Paradoxically, the Europarties themselves have by no means consistently and persistently advocated proposals which would have strengthened their own position and promoted a 'real' European polity, undoubtedly as a result of the internal differences of opinion within these transnational organisations regarding the desired degree of European integration.

In Chapter 7, Nicolle Zeegers focuses on one of the genuinely new developments in EU citizenship: the ECI, which was introduced by the 2009 Lisbon Treaty. An ECI is an initiative from EU citizens who have set up a citizens' committee that is registered by the European Commission. Within a year, this committee has to gather a million signatures from EU citizens in at least seven Member States. If this is done successfully, the proposed legislation is on the Commission's official agenda. In her contribution, Zeegers analyses the question of whether or not the ECI actually provides influence for EU citizens over the policy agenda of the Union and, if so, under which circumstances. Zeegers places the development of the ECI in the grander framework of the so-called 'new politics'; a more theatrical form of decision-making in which less traditional actors such as pressure groups play an important role. Since the EU has traditionally been a forum where decision-making has mostly been shaped from the inside, an outside form of influencing such as the ECI needs to take into account this internally-oriented model. Nevertheless, especially the Commission has been keen to strengthen the influence of citizens and organized citizens' groups because the EU's citizens are at the core of what the $\mathrm{EU}$ is for.

Zeegers' analysis shows that in the first three years since the inception of the ECI, 27 proposals have been made, of which only two have been successful: Right2Water (a campaign against the privatisation of water companies) and Stop Vivisection. A lot of ECIs are withdrawn during the period of signature-harvesting because the organising committee fears that the number of signatures required would not be met. If withdrawn, a proposal can be tried again later and support can be organised meanwhile. Zeegers concludes that the question of how far citizens' initiatives actually shape or influence policy-making at the EU level can be analysed best through the method of Social Network Analysis. Using this method, it can be shown that some ECIs (such as New Deal 4 Europe), 
although not successful as such, have influenced and shaped the Commission's agenda through different policy agents taking up points brought forward by the citizen's committee involved.

The final chapter in the book, by Senka Neuman Stanivukovic, deals with a perspective on EU citizenship 'from outside': it analyses the way in which debates about citizenship and the qualities annexed to it are shaped by the 'Europeanisation' of this concept in a number of Central European states that have obtained membership in recent years. She focuses on three states: the Czech Republic, Slovakia and Croatia. All three are not just (fairly recent) Member States of the EU, but they are also post-partition states: hence they face particular challenges in reconciling the 'classic' state-centred status of citizen with the 'new' and 'disrupting' dimension of Europeanisation. After measuring the field of study as such, Neuman Stanivukovic proposes a new approach that has gained impact over the last few years: a focus on the mundane and everyday aspects of Europeanisation. This approach allows us to escape from the state/EU dichotomy and pay attention to the multifaceted realities that take shape 'in between'. Neuman Stanivukovic uses this approach for two case studies: pre-accession assistance instruments and corresponding territorial reform in the Czech Republic and Slovakia between 1996-2003, and the pre-accession assistance in Croatia between 2004-2013. In the Czech Republic and Slovakia, the necessary institutional reforms caused by the implementation of legal structures to deal with European financial burdens and benefits enabled civil society groups (making use of the dynamics of EU citizenship and the rights annexed to it) to push their agendas for societal reforms. Croatia too had to restructure parts of its domestic organisation to be able to take part in the Cohesion Fund and other EU financial measurements. The Croat case leads to comparable conclusions: both the decentralised political bodies and civil pressure groups gained from the process of Europeanisation by being able to influence the agenda-setting of the central state actors - or even replace them with their own.

An overview of the seven contributions to this book shows the merits of the interdisciplinary approach chosen. The historical dimension that the conceptual analysis of Van Rossem points at is elaborated upon by Van der Harst and Harryvan; the chapters by Nowak and Langer both focus on the development of the rights annexed to the idea of Union citizenship, but from a different methodological perspective. Procee and Voerman and Zeegers concentrate on the participation of citizens in the decision-making process of the Union, but where Zeegers elaborates on the actions of European citizens themselves through the citizens' initiative, Procee and Voerman concentrate on proposals by the classic 
intermediaries of political decision-making - political parties - to bring this action about.

These are some examples of the ways in which the different contributions to this volume strengthen each other and contribute to a better understanding of the multifaceted concept that is European citizenship. Overall, therefore, we feel that this volume is a useful contribution to the debate on the status and future of European citizenship.

European citizenship is not a static concept, however. In all its variety, this volume too is but a 'snapshot', freezing a development that has many characteristics of a 'river, constantly flooding in': the 2015 Delvigne case is but the latest example of just the legal developments in this field. It will be interesting, to say the least, to watch closely the developments around the exit of the United Kingdom from the Union; it has already become clear that the rights of British nationals residing in the Union and the rights of EU citizens residing in the UK will be among the most important features of the final settlement of separation. This in itself shows already how important EU citizenship as a constitutional and political status has become since its legal inception in 1993.

Where will European citizenship be in, say, 25 years? Will the 50th anniversary of the Maastricht Treaty still lead to new volumes on European citizenship? We don't know. But one thing seems clear. If the EU survives the next quarter-century, European citizenship probably will still be a part of its constitutional and political framework. And if that is so, it probably will still be an important part of that framework. Perhaps by then, the time will have come in which the citizenship of the Union has become the prime legal status of the inhabitants of the EU. And if that is the case, some successors of ours will probably be editing a new volume on the meaning of EU citizenship for their today. For now, we hope that this volume will contribute to a better understanding of EU citizenship for our own. 